\title{
Defining Crimes in a Global Age: Criminalization as a Transnational Legal Process
}

\author{
Ely Aaronson and Gregory Shaffer
}

\begin{abstract}
The design of empirical research and theory-building projects in the sociolegal literature on criminalization is often premised on a presumed dichotomy between domestic and international planes of criminal lawmaking. However, in a global era in which domestic processes of criminalization are increasingly shaped by norms, institutions, and actors developed and operating outside national borders, criminalization research should develop a new theoretical frame for studying how international and domestic practices of criminal lawmaking interact with one another. This article builds from the theory of transnational legal orders and the recursivity of law to propose a transnational processual theoretical framework for the study of criminalization. This framework provides tools for investigating how criminal prohibitions are constituted through recursive interactions between actors operating in international, national, and local sites of legal practice. It draws on empirical studies to show how the processes of constructing, applying, and contesting definitions of international and transnational crimes are embedded in broader structures of power. The article demonstrates how a processual theory of transnational criminalization sheds light on important sociolegal questions about the driving forces and consequences of current efforts to harmonize the definitions of criminal activities across national jurisdictions.
\end{abstract}

In memory of Sally Merry, colleague, mentor, friend ${ }^{1}$

\section{INTRODUCTION}

Law and society scholars have long sought to explain the conditions under which new criminal prohibitions emerge, as well as the consequences of labeling behaviors as

\footnotetext{
Ely Aaronson is a senior lecturer at the University of Haifa, Faculty of Law, 199 Aba Khoushy Ave. Mount Carmel, Haifa, Israel 3498838. Email: aharonso@law.haifa.ac.il.

Gregory Shaffer is Chancellor's Professor and Director of the Center on Globalization, Law, and Society (GLAS) at the University of California, Irvine School of Law, 401 East Peltason, Irvine, California 92697. Email: gshaffer@law.uci.edu.

An earlier version of this article was presented at the annual meeting of the Law and Society Association (May 2020). The authors wish to thank Terence Halliday, Nicola Lacey, Itamar Mann, Nancy Reichman, Yair Sagy, Wayne Sandholtz, and the anonymous reviewers of Law $\mathcal{E}$ Social Inquiry for their excellent comments on an earlier draft. The research was supported by the Israel Science Foundation (Grant \#1281/14).

1. Sally's comments were invaluable to this article and broader project. She concluded our book Transnational Legal Ordering of Criminal Justice (Merry 2020). Her influence carries on in this work, and so much more.
} 
crimes (Hagan 1980; Jenness 2004; Lacey 2009). Why do societies come to define particular behaviors (and not others) as criminal? How does criminalization differ from and interact with other tools of constructing social meanings and regulating individual conduct? Under what conditions does criminalization affect social norms and behaviors? The rich body of scholarship addressing these questions demonstrates how criminalization policy serves as the product and catalyst of wider processes of constructing collective values and identities, negotiating intergroup relations, and building the regulatory capacities of government bureaucracies. Our understanding of the social functions and meanings of criminalization, however, remains radically incomplete so long as the design of empirical research and theory-building projects in this field are methodologically nationalist, thus dichotomizing the study of international and national processes of criminal lawmaking (Beck and Sznaider 2010).

In their important critique of methodological nationalism, Andreas Wimmer and Nina Glick Schiller $(2003,579)$ observe that many of the frames used by researchers across social science disciplines are designed as if the "web of social life was spun within the container of the national society, and everything extending over its borders was cut off analytically." This observation seems apt when applied to conventional frames for theorizing criminalization processes. Much of the research in this field reflects a methodological orientation that approaches the study of domestic processes of criminal lawmaking as if they were effectively isolated from foreign and international influences (Nelken 2011a, 1; Aas 2013, 199). Over the past two decades, the research agenda of the sociology of criminalization has expanded in light of the growing scholarly interest in studying the processes through which certain categories of conduct are defined as international crimes prosecutable by international tribunals (Hagan and Greer 2002; Hagan and Levi 2005; Hagan, Levi, and Ferrales 2006; Meierhenrich 2014; Levi, Hagan, and Dezalay 2016). This literature represents an important step toward improving our understanding of how criminalization practices operate beyond the national level. However, it has primarily focused on the practices of actors operating in international institutions rather than on the interaction between international and domestic processes of criminal lawmaking. In this article, we add a new layer to the scholarship on the internationalization of criminal law by developing and applying a theoretical framework for studying how practices of criminalization at the international, national, and local levels interact dynamically and recursively over time.

Domestic processes of criminal lawmaking in today's globalized world are increasingly subjected to international and regional forms of legal ordering. Hard and soft law instruments establishing common transnational standards increasingly shape decisions about whether to criminalize certain conduct (Nelken 2013, 142-43). This development reflects, more generally, the increased roles of intergovernmental organizations, transnational regulatory networks, supranational courts, and transnational nongovernmental organizations (NGOs) in shaping the parameters of domestic policies in different domains (Keck and Sikkink 1998; Barnett and Finnemore 2004; Slaughter 2004; Calliess and Zumbansen 2010; Shaffer 2015; Block-Lieb and Halliday 2017). In diverse areas addressing questions of human rights, financial regulation, counterterrorism, immigration control, narcotics control, and environmental regulation, the processes of constructing criminal prohibitions can no longer be viewed through a purely or predominantly national lens (Boyle and Preves 2000; Merry 2006a; Jakobi 2013; 
Shaffer, Nesbitt, and Waller 2015). In the face of these transformations, criminalization theory needs new tools to explain how transnational norms and institutions influence domestic practices of defining criminal prohibitions, as well as how these transnational initiatives change over time.

We offer a way forward by developing and applying a processual theoretical framework for studying transnational criminalization. We define criminalization as a set of processes through which actors construct legal norms that label certain activities as crimes. This definition encompasses both formal processes of statutory and judicial lawmaking that define criminal behavior (law on the books) and everyday practices of law enforcement that determine the application of criminal prohibitions (law in action) (Lacey and Zedner 2017, 59). Criminalization processes are transnational when they involve interactions between actors operating beyond and across national boundaries. We posit that the internationalization of criminal law is best understood through a theoretical lens that not only assesses how prohibition norms are being formalized at the international level, but also evaluates the domestic impacts of these norms. To facilitate such inquiry, we seek to bring criminalization theory into dialogue with sociolegal scholarship on transnational legal ordering and the development of transnational legal orders.

Over the past decade, the theory of transnational legal orders (TLOs) has developed a distinctive conceptual framework for analyzing the processes through which transnational legal norms are framed, propagated, settled, institutionalized, contested, and changed (Shaffer 2013, 2016; Halliday and Shaffer 2015; Shaffer, Ginsburg, and Halliday 2019; Shaffer and Aaronson 2020). Unlike traditional approaches in international law and international relations scholarship, TLO theory emphasizes that the processes of constructing transnational norms are not simply top-down and linear. Instead, these processes integrate top-down, bottom-up, and horizontal forms of lawmaking and practice, and they involve recursive interactions between actors wielding lawmaking power at different levels of social organization, from the transnational to the local. TLO theory builds concepts for empirical study of how transnational and domestic actors promote the global diffusion of particular norms and institutional forms, and how domestic actors generate, translate, adapt, appropriate, and resist transnational norms. As this article demonstrates, the conceptual tools of TLO theory provide criminalization scholars with fruitful ways for analyzing the production of transnational prohibition norms, their diffusion across borders, their complex regulatory impacts, and their change over time.

This article adopts a processual sociological framework (Liu 2013; Abbott 2016; Block-Lieb and Halliday 2017; Merry 2020). Unlike much research that depicts criminalization as a fixed outcome (the formal inclusion of a criminal prohibition in a legally binding text), we conceptualize criminalization as an ongoing process (Lacey 2009) and seek to elucidate how acts of transnational criminal lawmaking produce a series of recursive legal changes over time. Drawing on recursivity theory (Halliday 2009), we assess how these changes are driven by mechanisms such as diagnostic struggles between legal (and other) professionals, the indeterminacy of legal norms, ideological contradictions internalized within the law, and the mismatch between the actors who frame transnational legal norms and those implementing them in national and local contexts. We explain how norm entrepreneurs (Finnemore and Sikkink 1998) promote the creation of various legal ordering instruments that shape transnational criminalization processes. 
We examine why norm entrepreneurs direct their efforts toward particular forms of transnational lawmaking, and how such legal mobilization activities give rise to criminalization duties in a wide variety of hard and soft law instruments, including international treaties, UN declarations, model laws, legislative guides, and prescriptive indicators. However, in contrast with theoretical approaches that focus exclusively on the formation of prohibition norms at the international level, the transnational processual theoretical framework (or TLO framework) assesses how such episodes of international lawmaking trigger legal changes at the national and local levels. ${ }^{2}$ In particular, we consider how domestic actors who serve as intermediaries between transnational normmaking and domestic implementation and practice shape the legal and social meanings of criminal prohibitions through various practices of norm adaptation and norm contestation. As this article demonstrates, this processual approach illuminates the complex implications of transnational criminalization processes by focusing on how domestic implementation shapes regulatory and cultural impacts in ways that are often inconsistent with norm-making initiatives' goals.

The next section assesses the limitations of leading theoretical approaches for studying the construction and diffusion of transnational prohibition norms. While noting that these theories illuminate important social, cultural, and political dimensions of transnational criminalization processes, this section identifies their explanatory limits and it challenges some of their underlying premises. The next section outlines the main components of the transnational processual theoretical framework for studying criminalization, and situates it within the wider body of sociolegal research on transnational legal ordering and the recursivity of transnational legal change. The following two sections then examine the explanatory power of this theoretical framework by offering new interpretations of how transnational prohibition norms emerge and evolve at the international level and how these norms are reconstituted in national and local contexts. We conclude by discussing the contribution of this theoretical framework to understanding the complex consequences of transnational criminalization processes, together with methodological tools to apply it.

\section{THE TRANSNATIONAL DIFFUSION OF CRIMINAL PROHIBITIONS: EXISTING APPROACHES}

Much of the literature on the relationship between globalization, crime, and crime control measures is functionalist, depicting the emergence of new instruments for harmonizing criminalization policies as a natural response to changes taking place in the organization of illicit markets (for a critical analysis of this explanatory approach, see Andreas 2015). Processes of globalization have vastly extended and intensified the flow of people, goods, capital, information, and technology across national borders (Held and McGrew 2003). These processes create facilitative conditions for the production, financing, and trafficking of illicit goods and services, including the smuggling of

2. We adopt the term "transnational processual theoretical framework" in parallel to the TLO framework because some readers have misread the term "order" in Transnational Legal Orders to suggest that such orders are fixed and static, rather than dynamic and recursive. That is not the case with TLO theory, but we use the term transnational processual theoretical framework, in parallel, to avoid this confusion. 
banned commodities (such as drugs, guns, and counterfeit goods), the "laundering" of illegally obtained profits, and clandestine border crossing and exploitation of migrants (Williams and Vlassis 2001; Castells 2010, 171-214). From this functionalist perspective, globalization's criminogenic effects spur political initiatives to harmonize countries' criminal laws to facilitate interstate cooperation and coordination to combat such crime (Boister 2003, 957).

Accounts that focus on the role of large-scale changes in the operation of illicit markets help to illuminate the facilitative circumstances giving rise to new transnational prohibition norms. However, their explanatory power is inevitably partial as long as they fail to analyze the role of micro-level practices of issue-framing and lawmaking in shaping these norms' content and forms of institutionalization (Christensen and Levi 2017). Such accounts echo a tendency to assume that legal definitions of crime reflect an objective ontological reality rather than contingent outcomes from complex political struggles (Hulsman 1986; Kotiswaran and Palmer 2015, 71).

Theories focusing on the cultural dimensions of globalization offer a partial remedy to this problem because they illuminate how homogenizing cultural trends facilitate shared conceptualizations of the nature of social problems, which underpin the formation of global definitions of criminality. World polity theory (Meyer et al. 1997) illuminates how the global diffusion of legislative and institutional forms is not necessarily driven by changes in the nature of the behaviors they intend to regulate but, instead, by changes in the cognitive frames through which actors assess the legitimacy of these behaviors. Scholars within this tradition argue that the global diffusion of models of criminal legislation reflects isomorphic trends in which actors in different countries adopt the beliefs and patterns that prevail in the surrounding global environment (Jakobi 2013). For example, David John Frank and his colleagues (Frank, WosickCorrea, and Hardinge 2009) identify a remarkable worldwide trend in which the definitional scope of the offense of rape has expanded. They explain these findings as a product of the global diffusion of individualistic and dignity-affirming ideological frames and accompanying policy templates.

The theoretical framework developed in this article shares with world polity theory a constructivist sociological orientation that focuses on how actors constitute the meaning of social reality. However, it differs from this theory in two critical ways for developing a sociological understanding of transnational criminalization processes. First, much of the world polity theory literature depicts legal diffusion as a one-step move in which legislative models travel from the center to the periphery of the international system (Halliday and Shaffer 2015, 25). In contrast, the transnational processional (TLO) theoretical framework is premised on a processual sociological approach (Abbott 2016) that depicts criminalization as an ongoing process of negotiating the interpretive meanings of legal norms. As part of this process, domestic actors who institutionalize and apply transnational norms in national and local contexts are able to reformulate these norms' meaning and affect their regulatory performance. Second, although world polity theory does not predict that states will rigorously implement the global scripts they adopt, it places considerable emphasis on the isomorphic impact of transnational processes of norm diffusion. As a result, world polity theory has relatively little to say about the question of why different states (and different institutional actors within the same state) respond differently to the homogenizing forces that 
operate in the global environment (Boyle 2002, 99). To answer this question, a transnational processual theoretical framework provides tools to investigate how the institutional positioning, identities, expressive purposes, and differential capacities of the various actors who participate in transnational criminalization processes shape the ways in which they influence outcomes.

It is often observed that the emphasis of world polity theorists on the cultural driving forces of globalization processes cause them to underplay the role played by economic and political power relations in driving the global diffusion of policy templates (Finnemore 1996). In contrast, work premised on global prohibition regimes theory focuses on how power asymmetries in the international system shape the global diffusion of criminal law (Nadelmann 1990; Andreas and Nadelmann 2006). Global prohibition regimes theory emphasizes the role of powerful states (in particular, the United States) in shaping the international crime control agenda and in inducing states to join international regimes that promote hegemonic models of criminal legislation and policing. It shows how the effort to globalize US-style models of crime control serves as a major driver of change in other countries' domestic criminal justice policies (Andreas and Nadelmann 2006, 14).

The transnational processual theoretical framework shares with the global prohibition regimes approach a common interest in studying the power structures underpinning the formation and propagation of prohibition norms. However, as part of a wider effort to go beyond the limitations of regime theory (Halliday and Shaffer 2015, 21-24), we challenge two premises of global prohibition regimes theory. First, we posit that this theory fails to explain the impact of domestic cultural, political, and institutional factors on the interpretation, contestation, and revision of transnational prohibition norms. The global prohibition regimes literature tends to focus on visible indicators of participation in treaty regimes rather than on their highly variable forms of implementation. The transnational processual theoretical framework, in contrast, conceptualizes domestic lawmaking practices as integral components of the recursive processes through which particular interpretations of the scope and meaning of transnational prohibition norms are formed. This approach illuminates the role of bottom-up and horizontal normmaking processes that shape the development of transnational criminalization, an issue conspicuously understudied in the global prohibition regimes literature.

Second, like much of the international relations scholarship analyzing the formation of legal instruments promoting international cooperation against criminal activities (for example, Gardner 2015), global prohibition regime theory is state-centric, and it tends to conceptualize states as unitary actors. The transnational processual theoretical framework, in contrast, disaggregates the state (Shaffer and Halliday forthcoming). It assesses how complex dynamics of cooperation and competition between different domestic governmental and civil society actors seeking to promote different professional and political interests shape the formation and implementation of state policies. This emphasis on the disaggregated nature of the state sheds light on important sociolegal dimensions of criminalization processes. For example, it enables one to investigate how the policy scripts promoted by the United States and other powerful states are shaped by struggles between domestic interest groups within those countries, and how the efforts to implement these policy scripts in different national and local contexts, in turn, are facilitated and hindered by domestic actors serving as intermediaries 
between global and domestic lawmaking processes (Carruthers and Halliday 2006; Merry 2006a). This aspect of transnational processual theory helps to examine dimensions of power overlooked by competing theoretical approaches (Cotterrell 2012, 520 21). Whereas global prohibition regime theory ultimately focuses on a single macro concept of power (the capacity of powerful states to coerce weaker ones to join crime suppression treaties and comply with them), transnational processual theory provides a framework for investigating the relationship between different modalities of power in shaping the meanings of globalized prohibition norms (including the agenda-setting capacities of professional experts and activists, and the power of transnational norms to shape the legal consciousness of actors, including those who wield lawmaking powers within states) (Barnett and Duvall 2005).

\section{OUTLINE OF A PROCESSUAL THEORY OF TRANSNATIONAL CRIMINALIZATION PROCESSES}

A major goal of this article is to improve understanding of how recursive interactions between actors operating in international, national, and local sites of criminal lawmaking shape criminal prohibitions. Our starting point is to show how sociolegal work on the recursivity of legal change (Halliday and Carruthers 2007a; Halliday 2009; Liu and Halliday 2009) helps to illuminate the nature of the relationship between lawmaking processes taking place at these levels. Halliday and Carruthers (2007a) identify four mechanisms that drive recursive lawmaking processes: diagnostic struggles in which actors promote competing conceptualizations of the nature of a social problem, the indeterminacy of the legal norms adopted to address the problem, the contradictions that the texts may contain, and the mismatch between the actors formulating transnational norms and the actors who implement them in domestic settings. Transnational processual theory assesses how these mechanisms of recursive legal change affect criminalization. It explains how prohibition norms become embedded in transnational scripts and how these norms are contested and adapted across different sites of transnational and domestic lawmaking.

Within the tradition of social constructivist scholarship on the role of framing in shaping problem definition, causal interpretation, and policy recommendation (Goffman 1974; Benford and Snow 2000), the concept of diagnostic struggles highlights the role of conflicts regarding the nature and causes of a perceived social problem in shaping the form and content of legal norms and implementation mechanisms to govern the problem (Halliday 2009, 278-279; Liu 2013, 674-76). The transnational processual theoretical framework delineated in this article employs the concept of diagnostic struggles to assess how contests over the labeling of certain types of human conduct as criminal shape the scope and meaning of transnational prohibition norms in international, national, and local sites of criminal lawmaking and practice. In the next sections, we consider how the unique challenges of resolving moral and empirical debates underpinning the labeling of conduct as criminal impede concordance in the ways in which actors interpret and implement prohibition norms across legal systems.

Transnational criminalization processes involve two types of diagnostic struggles: internal and external. Internal diagnostic struggles are conducted between actors who 
support the use of criminal law to address a social problem while disagreeing on how to delineate the criminal prohibition's scope of application. For example, during the negotiations of the Protocol to Prevent, Suppress and Punish Trafficking in Persons (commonly known as the Palermo Protocol), the effort to craft an internationally accepted definition of the offense of human trafficking became a battlefield between competing camps of norm entrepreneurs promoting contradictory conceptualizations of the nature of prostitution/sex work (Gallagher 2001; Chuang 2010; Nelken 2013). On one side, a coalition of neo-abolitionist activists sought to shape the treaty in accordance with a diagnostic frame that construes prostitution as inherently exploitative and degrading, a form of violence against women that must be abolished (MacKinnon 1993). This coalition sought to capitalize on the image of UN treaties as symbols of international consensus to reinforce the legitimacy of a diagnostic frame that classifies all forms of prostitution as crimes and denies the existence of meaningful distinctions between "forced" and "voluntary" forms of commercial sex. On the other side, critics of the neo-abolitionist paradigm promoted a diagnostic frame that emphasizes sex workers' agency and justifies criminalization only for those situations in which commercial sex acts are induced by force, fraud, or coercion (Chuang 2010, 1670-71). As is often the case, the offense definition that the Palermo Protocol eventually codified reflects a compromise between these two camps by using ambiguous legal concepts that gloss over ideological disagreements underlying the diagnostic struggle. On the one hand, the Protocol's definition of the trafficking offense refers to "exploitation of the prostitution of others" and "other forms of sexual exploitation"; on the other hand, it purposely leaves the concepts of "exploitation" and "consent" undefined, thus granting national lawmakers discretion in accordance with domestic preferences regarding the governance of prostitution/sex work.

From the viewpoint of transnational processual theory, the mechanisms that drive recursive processes (diagnostic struggles, actor mismatch, ideological contradictions, and textual indeterminacy) interact. Diagnostic struggles, for example, can give rise to compromises that, in turn, are reflected in textual indeterminacies and contradictions. These textual indeterminacies and contradictions, in turn, provide tools that actors can exploit at the time of domestic implementation and practice. They similarly can restimulate diagnostic struggles over the nature of the targeted problem to be addressed.

Unlike a sizable body of literature examining the strategic advantages that norm entrepreneurs gain by choosing particular forms and institutional venues of transnational lawmaking (for example, Abbott 2001), the processual approach opens inquiry regarding how initial successes in shaping the content of treaties and soft law instruments may erode over time through transnational and domestic practices of norm contestation (Weiner 2018). Even when an international treaty reflects the normative propositions of a particular diagnostic frame, competing conceptualizations of the nature of the problem can affect how the treaty norms are interpreted and applied (Kotiswaran and Palmer 2015, 60-62). In some cases, the persistence of diagnostic struggles may erode transnational prohibition norms that appeared to be settled following the conclusion of a crime suppression treaty, such as when local actors harness textual indeterminacies. 
For example, the question of whether legal definitions of crimes against humanity should cover the activities of corporations has been the subject of a long controversy dating back to the Nuremburg trials (Bush 2009). During the negotiations of the Rome Statute, the idea of authorizing the International Criminal Court (ICC) to pursue criminal charges directly against corporations was rejected on a number of conceptual and practical grounds (Kaleck and Saage-Maass 2010). However, diagnostic struggles over whether to interpret the prohibitions codified in the Rome Statute in ways that apply to the activities of multinational corporations persist in a variety of transnational and domestic contexts. In the wake of public debates over the involvement of multinational corporations in war zones and conflict areas and their role in facilitating state-sponsored human rights violations and large-scale environmental hazards to human health, international and regional lawmakers are increasingly adopting policy scripts that urge national lawmakers to expand domestic statutory definitions of corporate liability. In 2016, the European Parliament issued a resolution calling on European Union (EU) member states to enact criminal liability for corporate actions that constitute serious human rights abuses. ${ }^{3}$ In the same year, the Office of the Prosecutor of the ICC declared that it "will give particular consideration to prosecuting Rome Statute crimes that are committed by means of, or that result in, the destruction of the environment, the illegal exploitation of natural resources or the illegal dispassion of land" (Office of the Prosecutor of the International Criminal Court 2016, 5). These policy prescriptions have stimulated national prosecutors and courts to adopt more expansive definitions of atrocity crimes (Cryer, Robinson, and Vasiliev 2017, 73). Although the bulk of existing research on the construction of atrocity crimes focuses predominantly on actors operating at the international level, the transnational processual theoretical framework illuminates how domestic implementation practices can spur recursive processes affecting the meaning of these norms. Recent proposals to include new norms of criminalizing corporate activities in the UN-backed treaty on Business and Human Rights (Darcy 2017) illustrate this recursive path of transnational lawmaking.

A second type of diagnostic struggle shaping the contours of transnational criminalization processes involves disagreements over whether a social problem should be addressed through criminal law measures or alternative policies. These external diagnostic struggles bring norm entrepreneurs advocating the creation of new criminal prohibitions into conflict with actors who highlight the counterproductive impacts that criminalization often engenders, including the creation of black markets, the strengthening of criminal organizations, and the displacement of regulatory frameworks for tackling the root economic and social causes of the targeted activities (Naylor 2002; Bowling 2011). In this context, too, the transnational processual approach emphasizes how such contests affect not only the production of transnational prohibition norms but also subsequent stages of implementing them.

For example, advocates have debated whether the personal use of cannabis should be criminalized since at least the late nineteenth century (Shamir and Hacker 2001). Throughout the second half of the twentieth century, war-on-drugs crusaders initiated three widely ratified UN drug control conventions firmly grounded in a prohibitionist

3. European Parliament Resolution of 25 October 2016 on Corporate Liability for Serious Human Rights Abuses in Third Countries (2015/2315(INI)). 
diagnostic frame. The preamble to the Single Convention on Narcotic Drugs (1961) exemplifies this frame, declaring: "[A]ddiction to narcotic drugs constitutes a serious evil for the individual and is fraught with social and economic danger to mankind." However, the proposition that the personal use of drugs — and most notably, cannabisshould be treated as a punishable offense remained contested in many countries (BewleyTaylor 2012). Over time, such contestation catalyzed national and local legal reforms, eroding the prohibitionist norms that appeared to be settled at the international level (Aaronson 2019). Some countries retained the statutory prohibition on the possession of cannabis while initiating implementation policies that use civil rather than penal measures of enforcement (Ibid 90-91). Other countries introduced statutory reforms decriminalizing or legalizing medical or recreational uses of the drug (Laqueur 2015). Recently, this emergent trend of domestic cannabis liberalization reforms led actors in the international drug control system — such as the World Health Organization and the United Nations Office on Drugs and Crime- - to revise their long-standing policy positions and support harm reduction principles. As this example demonstrates, ongoing diagnostic struggles about whether a formally prohibited conduct deserves to be treated as a crime (with all the moral baggage that such a label entails) trigger changes in the scope and meaning of transnational prohibition norms. Horizontal and bottom-up norm-making processes, in which domestic actors import legal definitions from other jurisdictions and promote norm-diffusion trends, stimulate international lawmakers to revise earlier conceptualizations of the nature of the targeted social problem.

Transnational recursivity theory urges examination of how pressures to manage the uncertainties that arise from the indeterminacy and contradictions of legal texts catalyze the production of new legal rules, standards, and institutional arrangements (Halliday 2009, 281-82). This approach provides new understanding of the age-old social legal phenomenon of the gap between the law on the books and the law in action (Gould and Barclay 2012, 331-34) by showing the mechanisms through which the law in action can reshape the law in the books. We follow this line of inquiry by considering how disagreements regarding the implementation of transnational prohibition norms generate new episodes of criminal lawmaking at the transnational, national, and local levels. This focus allows us to place the conceptual tool of actor mismatch on the research agenda of the sociology of criminalization. The concept of actor mismatch directs attention to the difficulty of achieving concordance in the interpretation of a legal norm in international, national, and local settings because of the divergent interests and values of the relevant actors wielding lawmaking power at each level (Halliday and Carruthers 2007a, 1152-53; Halliday 2009, 277-78). The actors who play pivotal roles in setting the agenda of treaty negotiations and drafting treaty norms do not necessarily share the interests and values of actors wielding norm-making power in other sites of transnational lawmaking, such as at the levels of national enactment and local practice. The policy preferences of domestic actors who have the capacity to facilitate or resist the implementation of transnational prohibition norms are often marginalized in international lawmaking forums. As a result, these actors may interpret and apply prohibition norms in ways that are inconsistent with their settled meaning at the international level. Indeterminacies and ideological tensions within international legal texts, such as a result of compromise, facilitate their ability to do so.

In this light, the transnational processual theoretical framework shows how domestic lawmaking and implementation affect the meaning of prohibition norms at the 
international level. The conclusions of crime suppression treaties often stimulate actors operating under the auspices of international organizations, the US State Department, and the European Commission, among others, to create new legal ordering instruments to guide national implementation. Instruments such as prescriptive indicators and model laws are integral components of ongoing processes of negotiating, adapting, and contesting transnational prohibition norms (Merry, Davis, and Kingsbury 2015). The transnational processual approach calls for investigation of the techniques that powerful national governments and international organizations use to overcome some of the barriers posed by consent-based procedures of formal international lawmaking (Krisch 2014) in order to establish standards of criminalization that are stricter than those agreed upon during the formation of international crime conventions. It also foregrounds how these powerful governments and international organizations may frame their policies through interactions with domestic stakeholders and transnational professional and political actors who promote competing agendas. As we demonstrate below, through utilizing the concept of actor mismatch to analyze the interactions between different actors wielding influence in transnational criminal lawmaking processes, the transnational processual framework offers a more nuanced, multifaceted account of the modalities of power underpinning the formation of transnational prohibition norms. Such an account integrates analysis of the influence that powerful states and international organizations wield in these processes with analysis of the agenda-setting power of domestic constituencies and transnational private stakeholders that implicate the strategies and positions of such powerful states and international organizations. In other words, weaker actors can shape the construction of the strategies of more powerful actors.

The concept of actor mismatch is also helpful in illuminating how interactions between legislatures, judges, and law enforcement officials within national legal systems recursively shape the meaning of transnational prohibition norms. Recent strands in the sociology of criminalization emphasize how decisions about whether or not to label behaviors as crimes are taken across a variety of institutional domains within the state (Stuntz 2001; Lacey 2009). Domestic criminalization processes involve complex interactions between diverse actors wielding different forms of lawmaking power. These actors include legislatures who formulate statutory definitions of criminal prohibitions, police officers and prosecutors who decide whether specific behaviors that potentially violate these statutory prohibitions pass the threshold of social disapproval justifying the initiation of criminal investigations and charges, and judges who interpret and apply statutory criminal prohibitions in light of broader constitutional and doctrinal principles (Duff et al. 2014, 11). Extant theories of the construction of international and transnational crimes focus on lawmaking processes that occur beyond the state. These theories overlook the ways in which interpretive disagreements between state actors who form part of the overall legal complex within a state (Karpik and Halliday 2011) shape the implementation of transnational prohibition norms. The transnational processual theoretical framework, in contrast, acknowledges that such disagreements emanate from structures underlying interinstitutional frictions-most notably, the fact that legislatures, police officers, prosecutors, and judges differ from one another in terms of their professional backgrounds, their organizational interests, their degrees of susceptibility to pressure from domestic interest groups, and the strength of 
their ties with transnational actors (Stuntz 2001; Yoo and Boyle 2015). In light of the indeterminacy of transnational prohibition norms and the ideological contradictions they often contain, we predict that these actors are likely to adopt divergent interpretations of the scope and meaning of prohibition norms. The transnational processual theoretical framework assesses the conditions under which the interpretive constructions of different state actors converge, leading to normative settlement (Grattet, Jenness, and Curry 1998). As we demonstrate below, when these interpretive practices are out of sync, these norms are less likely to achieve their promoters' regulatory goals.

The transnational processual theoretical framework enables criminalization scholars to attend to the methodological challenge encapsulated in Saskia Sassen's (2013, 30) observation that "the global—whether an institution, a process, a discursive practice or an imagery-both transcends the exclusive framing of national states and partly emerges and operates within that framing." In the next section, we apply this theoretical framework to offer a new interpretation of how the construction of prohibition norms transcends the boundaries of nation-states. The ensuing sections then apply this framework to analyze how the meaning of prohibition norms is reconstituted over time, including through developments within national and local contexts.

\section{TOWARD A PROCESSUAL THEORY OF THE CONSTRUCTION OF PROHIBITION NORMS BEYOND THE STATE}

The number of multilateral treaties formalizing duties to criminalize acts, the range of issues covered by these treaties, and the variety of actors participating in their formation have significantly increased in recent decades (Boister 2012, 13). Soft law instruments and transnational governance tools establishing global standards of criminal lawmaking have proliferated in parallel (Andreas and Nadelmann 2006, 5). In this section, we summarize these trends and reflect on the theoretical challenges they pose for the sociology of criminalization. We demonstrate how the theory of transnational criminalization processes outlined in the previous section improves our understanding of the various dimensions of the processes through which prohibition norms emerge and institutionalize beyond the national level.

\section{Treaty-Making Processes and the Construction of Transnational Prohibition Norms}

In the final decades of the twentieth century, states increasingly used multilateral treaties to formalize transnational prohibition norms, shadowing earlier efforts during the League of Nations era to address transnational crimes such as "white slavery," "anarchist terrorism," and drug trafficking (Knepper 2010). Between 1988 and 2003, in what was a historic high point of treaty-making to address crimes of international concern, states concluded eight multilateral treaties, which involved the vast majority of states. As Table 1 shows, these treaties established international criminalization duties in areas ranging from corruption and human trafficking to terrorism finance and war crimes. 
TABLE 1.

Crime Suppression Treaties with Broad (100+) International Membership, 19882003

\begin{tabular}{|c|c|c|c|}
\hline$\underline{\text { Issue area }}$ & International treaties & $\begin{array}{c}\text { Year of } \\
\text { conclusion }\end{array}$ & $\begin{array}{c}\begin{array}{c}\text { Number of } \\
\text { signatory states }\end{array} \\
\end{array}$ \\
\hline Drugs & $\begin{array}{l}\text { UN Convention against Illicit Traffic in Narcotic } \\
\text { Drugs and Psychotropic Substances }\end{array}$ & 1988 & 190 \\
\hline Atrocity crimes & Rome Statute of the International Criminal Court & 1998 & 123 \\
\hline $\begin{array}{l}\text { Transnational } \\
\text { organized } \\
\text { crime }\end{array}$ & $\begin{array}{l}\text { The UN Convention against Transnational } \\
\text { Organized Crime }\end{array}$ & 2000 & 184 \\
\hline $\begin{array}{l}\text { Human } \\
\text { trafficking }\end{array}$ & $\begin{array}{l}\text { Protocol to Prevent, Suppress and Punish } \\
\text { Trafficking in Persons, especially Women and } \\
\text { Children }\end{array}$ & 2000 & 173 \\
\hline $\begin{array}{l}\text { Human } \\
\text { smuggling }\end{array}$ & $\begin{array}{l}\text { Protocol against the Smuggling of Migrants by } \\
\text { Land, Sea and Air }\end{array}$ & 2000 & 145 \\
\hline $\begin{array}{l}\text { Illicit trade in } \\
\text { small arms }\end{array}$ & $\begin{array}{l}\text { Protocol against the Illicit Manufacturing of and } \\
\text { Trafficking in Firearms }\end{array}$ & 2000 & 113 \\
\hline $\begin{array}{l}\text { Terrorism } \\
\text { finance }\end{array}$ & $\begin{array}{l}\text { The International Convention for the } \\
\text { Suppression of the Financing of Terrorism }\end{array}$ & 2002 & 187 \\
\hline Corruption & The UN Convention against Corruption & 2003 & 183 \\
\hline
\end{tabular}

In parallel, other international treaties included criminalization duties as part of their enforcement tools to address their issues. For example, the Agreement on Trade-Related Aspects of International Property Rights (TRIPS) obliges all 162 members of the World Trade Organization (WTO) to "provide for criminal procedures and penalties to be applied at least in cases of willful trademark counterfeiting or copyrights piracy on a commercial scale." Regional treaties also increasingly include duties to criminalize certain behaviors. Of the fifty-four member countries in the African Union, forty-nine signed the Protocol to the African Charter on Human and Peoples' Rights on the Rights of Women in Africa, which requires criminalizing female genital cutting. The European Union and the Council of Europe have devised treaty instruments and other legal tools (such as directives and framework decisions) to commit member states to criminalize activities regarding human trafficking, terrorism, cybercrime, corruption, immigration, money laundering, counterfeiting, and electronic payment fraud (Mitsilegas 2015).

Despite the increased use of treaties to create criminalization duties, the sociology of criminalization has not developed systematic tools to assess how treaty norms shape domestic criminal law. We posit that a key to understanding the distinctive role played by treaty norms in this context lies in their operation as iconic symbols of international consensus. Unlike other processes of transnational lawmaking, treaty-making processes require the formal expression of consent by a large number of national governments. This distinctive feature enables norm entrepreneurs that are capable of exerting influence over the formulation of treaty norms to enhance the legitimacy of diagnostic frames labeling particular activities as crimes. In particular, UN crime suppression 
treaties provide a powerful symbolic representation of the universal moral validity of the prohibition norms they establish, exemplifying what Inis Claude famously conceptualized as the "collective legitimizing function" of the UN system (Claude 1988, 45). "While the voice of the United Nations may not be the authentic voice of mankind," he observed, "its status as an institution approximating universality gives it obvious advantages for playing the role of the custodian of the seals of international approval or disapproval" (150). Although the UN's image as a benevolent organization has become increasingly contested in recent years, its ethos of commitment to the principle of sovereign equality helps to portray the treaty norms agreed upon under its auspices as transcending the parochial interests of individual states (Walker 2014, 61-63).

We posit that the role of treaties within transnational criminalization processes should be analyzed, in part, within a two-level game perspective (Putnam 1988), although our focus on the recursivity of law extends well beyond conventional twolevel game theory. The two-level game approach considers, on the one hand, how powerful states shape a treaty's negotiated outcomes, and, on the other hand, how private stakeholders and norm entrepreneurs shape the policy preferences of these states. This perspective improves understanding of the variable forms of power that drive transnational criminalization processes. For example, studies of the formation of transnational prohibition norms governing the criminalization of intellectual property rights (IPR) violations often focus on the role of power asymmetries between states that enable advanced industrialized countries to promote the global diffusion of restrictive models of criminal legislation in this field (Drezner 2007). A two-level framework calls attention to how domestic political actors shape the policies adopted by these national governments. As has been well documented, American business elites lobbied the US Congress to introduce federal legislation threatening the imposition of trade sanctions on foreign countries that failed to comply with specified IPR standards. That action was an integral component of the transnational legal process leading to the global diffusion of the criminalization of trademark counterfeiting and copyright piracy (Sell 2003). Likewise, business elites in advanced industrialized countries successfully pressed their governments to prioritize the criminalization of IPR violations in the negotiations of the agreements leading to the formation of the WTO, including the TRIPS agreement. In doing so, they sought to transform the social meanings of these activities, including in countries where IPR violations were not previously considered to be criminal. These campaigns sought to capitalize on the moralizing function of criminal law (Durkheim 1960) and catalyze a normative change in which issues that were once perceived as matters of legitimate cross-national variation in policy preferences-a reflection of diverging traditions of thinking about the degree of copyright protection that should be granted to artistic and scientific works (Alford 1997)—would be reframed as departures from the collective values of the international community.

As this example shows, although the inclusion of criminalization duties in widely ratified multilateral treaties creates a powerful symbol of broad international consensus regarding certain conduct, this technique of formalizing prohibition norms in treaties can heavily rely on coercive strategies (Efrat 2012, 51-53). National governments of weaker states endorsing such treaty commitments are often motivated by noncrime-related instrumental economic and reputational incentives (Broude and Teichman 2009, 843-44). The increasing use of treaty instruments to harmonize 
national criminalization policies since the 1980s has harnessed issue-linkage strategies that make access to trade and aid conditional on states' willingness to ratify international conventions. The United States and the European Union, due to the size of their domestic markets and their disproportionate influence on aid allocation, use these mechanisms by promising to open (or threatening to close) their domestic markets to foreign goods and by withholding aid from countries that refuse to commit to criminalizing certain behaviors (Hafner-Burton 2009; Bradford 2020). The transnational processual framework provides a distinctive lens for analyzing the consequences of these coercive techniques because it examines how the legitimacy deficits of treaty-making processes affect the ways in which norms are implemented in national and local settings. As we demonstrate below, the reliance on coercive issue-linkage strategies can compromise the ability of crime suppression treaties to change the normative frames through which domestic legal actors implement them in everyday settings.

Because treaties are designed to facilitate consensus across a broad spectrum of states that differ in their penal standards and constitutional structures, the texts often employ open-ended language and reflect contradictory ideological positions. Legal recursivity theory calls attention to ensuing dynamics neglected by mainstream international law scholarship. It posits that the very same feature that is usually identified as a cause of the weak direct influence of treaties on state behavior-namely, their limited capacity to set precise and enforceable obligations (Hathaway 2002) — can produce significant indirect influences by catalyzing new cycles of transnational lawmaking intended to resolve interpretive disagreements about the appropriate forms of implementing these obligations.

\section{Informal International Lawmaking and the Construction of Transnational Prohibition Norms}

The indeterminacy and inherent contradictions in prohibition norms can induce subsequent phases of recursive transnational lawmaking. During these subsequent phases, various transnational actors seek to establish authoritative interpretations of how states should apply and implement such norms. The range of actors participating in these interpretive struggles includes UN organs such as the UN Office on Drugs and Crime (Romaniuk 2010), international organizations that exercise expert authority in particular issue areas (such as the Financial Action Task Force (FATF) in the area of money laundering and terrorism finance) (Nance 2018), the US government (McLeod 2010; Friman 2015), the European Union (Mitsilegas 2015; Christensen 2017), and security governance networks (Bigo 2006). They deploy a variety of legal ordering instruments, including social indicators, model laws, best practices guides, and prescriptive standards (Halliday and Shaffer 2015, 43). Some of the instruments these actors deploy are not formally classified as valid procedures for promulgating international legal obligations. Their legal ordering function does not stem from their possession of formal attributes of international lawmaking, but from their capacity to induce and socialize domestic actors to apply their policy prescriptions (Pauwelyn, Wessel, and Wouters 2012). As Nico Krisch (2014) argues, it is the capacity of such legal ordering instruments to provide more hierarchical and flexible governance tools than those 
produced through the conventional (consent-based) procedures of international lawmaking that accounts for their increasingly salient role in governing globalization. This development has become more salient with the decline of the post-Cold War international order that previously facilitated the conclusion of multilateral treaties.

The area of human trafficking exemplifies the benefits of a transnational processual approach for understanding the transformation of the scope and meaning of prohibition norms. Soon after the conclusion of the Palermo Protocol, transnational actors developed new legal ordering instruments to shape the ways in which domestic legal actors interpret and apply the Protocol's provisions. Since 2001, the US Department of State has published an annual Trafficking in Persons (TIP) Report, which monitors and assesses the antitrafficking policies of countries across the globe (Chuang 2006). The report focuses on indicators such as the comprehensiveness of the statutory definitions of antitrafficking offenses, the annual number of prosecutions, and the sentences imposed on convicted offenders. Aid-recipient countries that fail to meet the framework's minimum criteria can face reductions in aid. A series of studies using large- $\mathrm{N}$ databases documented the influence of the US TIP Report framework on the domestic legal policies of other countries. Judith Kelley and Beth Simmons, for instance, observe: "When the United States first started monitoring, fewer than 10 percent of states had criminalized human trafficking in their domestic law. Now approximately 70 percent of all countries have done so" (Kelley and Simmons 2015, 60). They find that the placement of a country in one of the two lowest tiers in the TIP Report was the most robust explanatory variable for a country's willingness to pass tougher antitrafficking laws. (Other possible explanatory variables included the estimated intensity of a country's trafficking problem, the density of NGOs, and the representation of women in parliament.)

Importantly for our purposes, the impact of the TIP Report framework should be assessed not only by its role in catalyzing the global diffusion of antitrafficking laws, but also by its influence on these laws' content. Alongside its stated compliance-monitoring functions, the TIP Report framework performs informal lawmaking roles, setting more demanding criminalization standards than those agreed under the Palermo Protocol (Nelken 2015). For example, as noted earlier, one of the fiercest points of contention during the negotiation of the Palermo Protocol was how the antitrafficking convention should address the nature of the relationship between human trafficking and prostitution/sex work (Gallagher 2001). The failure to reach a consensus resulted in the deliberate decision to leave state parties the discretion to decide whether to define prostitution as a form of trafficking in domestic laws (Chuang 2014, 610). Many consider this ambiguity desirable, given the intractable epistemological and empirical questions underpinning this debate, including the question of how to define consent and how to assess its manifestations in the complex contexts of migration and sexual commodification (Kotiswaran 2011; Elliot 2015). However, in light of the unique status of the TIP Report framework as a global standard setter, the US government's approach to this vexing question gained considerable influence on the policy choices made by national legislatures in other countries (Kotiswaran 2019, 61-63). Responding to campaigns mobilized by a coalition of neo-abolitionist feminists, neoconservatives, and evangelical Christian groups in US political arenas (Bernstein 2007, 128; Efrat 2012, 179-85), the Bush administration regarded aspects of national antiprostitution laws as indicators of compliance with international antitrafficking norms. It did so notwithstanding the 
explicit clarification in the official interpretive notes to the UN Trafficking Protocol that its definitions are framed "without prejudice to how State Parties address prostitution in their respective domestic laws." As Anne Gallagher and Janie Chuang observe $(2012,338)$, the Bush administration "decided to use the TIP Report as a weapon in its international campaign against prostitution," operating "on the assumption that ... the criminalization of sex-buying, pimping, and brothel-keeping ... would lead to a reduction in sex trafficking cases." This case illustrates how domestic social movements in the United States serve as transnational norm entrepreneurs by enrolling the US government to wield influence and induce other countries to subject their citizens to new models of criminal prohibition.

An extensive body of literature criticizing the United States as a self-nominated "global sheriff" views the TIP Report framework as an example of hegemonic coercive tactics (Chuang 2006; McLeod 2010). The transnational processual (TLO) theoretical framework examines how coercive mechanisms drive the global diffusion of transnational prohibition norms. However, it also provides tools enabling criminalization scholars to go beyond an exclusive focus on compulsory forms of power. The processes of framing the policy prescriptions of the TIP Report involve ongoing debates about how to define human trafficking and how to operationalize criteria for measuring compliance with the norms enshrined in the Palermo Protocol. As an alternative to the conventional use of a state-centered prism to theorize the impact of the TIP Report (highlighting the capacity of the United States to coerce other countries to adopt its preferred models of criminalization), the processual theoretical framework calls attention to how two types of struggles shape the processes of framing and applying the TIP Report's definitions and compliance criteria: diagnostic struggles over the nature of the problem of trafficking and interpretive struggles over how the prohibition norms of the Palermo Protocol should be construed and applied.

The focus on diagnostic and interpretive struggles enables one to go beyond the conventional portrayal of the United States as a unitary actor relatively insulated from international influences. It opens a new contextual lens to analyze how dynamic interactions between domestic actors in the United States and transnational actors operating under the auspices of intergovernmental and nongovernmental organizations help frame the TIP Reports' policy scripts (Kotiswaran 2019). For example, in 2005, the International Labor Organization (ILO) launched a campaign linking its long-standing interest in abolishing forced labor with the antitrafficking movement's concerns. It criticized the TIP Report's dominant focus on sex work and its neglect of the labor exploitation of millions of workers outside the sex industry (Chuang 2014). The ILO's report, entitled A Global Alliance against Forced Labor, articulated a new diagnostic frame defining trafficking as a social problem that comprises both sexual and labor forms of exploitation. The report introduced a new system of quantifying the estimated number of trafficking victims and challenged the accuracy of the TIP Reports' estimates (Kotiswaran and Palmer 2015, 75). This criticism gained traction among transnational

4. Report of the Ad Hoc Committee on the Elaboration of a Convention against Transnational Organized Crime on the Work of Its First to Eleventh Sessions, Addendum, Interpretive Notes for the Official Records (Travaux Préparatoires) of the Negotiation of the UNODC, United Nations Convention against Transnational Organized Crime and the Protocols Thereto, Res A/RES/55/25, para $64(2000) 1$. 
NGOs. One of these NGOs, the Walk Free Foundation, successfully lobbied for the adoption of a broader diagnostic frame that includes a variety of "slavery-like" practices within the concept of trafficking, such as debt bondage, forced marriage, and sale or exploitation of children (Kotiswaran 2019, 64-65). The Foundation attracted significant media attention to its Global Slavery Index, a biannual report that ranks countries in terms of their "modern slavery" problem, which helped to diffuse this new frame of equating trafficking with "modern slavery." During the Obama administration, US NGOs and federal government agencies such as the Labor Department's International Labor Affairs Bureau (ILAB) and the State Department's Bureau of Democracy, Human Rights and Labor (DRL) endorsed these campaigns (Chuang 2014). This advocacy triggered revision of the standards used in the TIP Report to evaluate states' antitrafficking efforts to include consideration of whether countries criminalize forms of labor exploitation and slavery-like practices. As this case shows, even legal ordering instruments that openly rely on unilateral exercises of coercive state power are constructed through recursive engagement with policy models developed by other actors.

To summarize, a transnational processual account of legal ordering assesses the use of a variety of hard and soft law instruments formalizing transnational prohibition norms. This processual perspective enables researchers to examine the relationship between top-down, horizontal, and bottom-up norm-making processes that shape the formation, transformation, and operation of transnational legal ordering instruments governing criminalization policies. It provides a distinctive framework for assessing how ongoing interactions of domestic and transnational actors shape powerful states' and international organizations' objectives and strategies. It illuminates the complex interactions of different modalities of power (including the coercive capacities of powerful states, the agenda-setting power of norm entrepreneurs, and the legitimizing power of legal norms) that underpin the development of transnational prohibition norms. Importantly, however, transnational processual theory posits that even when there is a high degree of normative settlement at the international level (such as a seemingly broad consensus about the ways in which states should implement international duties of criminalization), these shared understandings of the prohibition norm's meaning do not necessarily concord with how national and local actors will interpret, implement, and apply it (Block-Lieb and Halliday 2015, 94). In the next section, we consider the factors shaping the domestic components of transnational criminalization processes.

\section{TOWARD A PROCESSUAL THEORY OF THE DOMESTIC CONSTRUCTION OF TRANSNATIONAL PROHIBITION NORMS}

As we noted earlier, an extensive body of literature tends to assume that states' geopolitical positioning and situational vulnerability to pressure from powerful countries and international organizations predominantly shapes participation in "global prohibition regimes" and regime outcomes (Nadelmann 1990). Such approaches, however, fail to consider how the indeterminacy and contradictions of legal texts enable national lawmakers to choose from among several options and foil powerful actors (Halliday and Carruthers 2007b). Transnational processual (TLO) theory, in contrast, proceeds from 
the premise that transnational legal norms are prone to containing ambiguous legal concepts as well as contradictory ideological elements (Halliday 2009, 280-82). Consequently, the transnational diffusion of prohibition norms provides domestic actors with considerable leeway to design models of implementation that reflect their interests and values. The new legal meanings constituted through these practices of translating global prohibition norms into local vernaculars (Merry 2006b) sometimes reinforce and sometimes deviate from the settled interpretations of these norms at the international level. In some cases, domestic acts of implementing transnational scripts of criminalization generate new processes of horizontal and bottom-up norm diffusion by providing models that lawmakers in other countries borrow and imitate (Halliday and Shaffer 2015, 60).

\section{Domestic Statutory and Judicial Constructions of Transnational Prohibition Norms}

Policy formation processes implementing transnational prohibition norms involve what Robert Reiner $(2016,2)$ describes as the inherently contested nature of the concept of crime. As Reiner notes, disagreements about the nature of the concept of crime pervade discussions about the criminalization of specific conducts so that "it is common for people to argue about whether something ought to be a crime or not, whether it really is criminal, how it should be treated, and so on" (Reiner 2016, 3; see also Henry and Lanier 2001). The inherently contested nature of the concept of crime enables actors to promote conflicting interpretations of how states should implement international duties of criminalization (Cotterrell 2015). Domestic actors serving as intermediaries between global norms and domestic legal practice deploy strategies of norm appropriation and norm contestation to shape the processes through which national lawmakers choose among alternative interpretations and implementation schemes (Shaffer 2012, 254-55). The ability of these actors to wield influence in the policy-making process depends on a number of factors, including the extent to which they are able to make credible claims to expertise, their ability to translate transnational scripts into policy frames that are seen as legitimate and appealing to domestic audiences, and the degree to which they are perceived as attentive to the needs and experiences of domestic constituencies in cases of conflict with the policy goals and values of transnational lawmakers (Carruthers and Halliday 2006, 529-31).

In the field of anti-money laundering legislation, for example, interest groups in various countries have developed lobbying and litigation strategies to persuade legislatures and judges to adopt narrow interpretive constructions of the prohibition norms developed by international organizations. There appears, at least nominally, to be considerable international consensus about the need to criminalize lawyers' breaches of duties to detect and report the suspected money flows of their clients. The FATF's Recommendations included the imposition of significant duties on such lawyers. So did the model legislation on money laundering and financing of terrorism issued by the International Monetary Fund (IMF) and the UN Office of Drugs and Crime, as did European Union Directives, among other sources (Sharman 2011; Nance 2018; Halliday, Levi, and Reuter 2019). However, despite this significant degree of normative settlement at the international level, domestic stakeholders in countries have been able 
to shape implementation strategies that narrow the scope of these criminal prohibitions. In Canada, for example, a constitutional litigation campaign conducted by Canada's Federation of Law Societies (a coordinating body of the nation's fourteen provincial and territorial law societies) led the Supreme Court to strike down as unconstitutional sections of the Canadian Proceeds of Crime Act that had stipulated sanctions for breaches of lawyers' record-keeping and reporting obligations. ${ }^{5}$ The Federation's campaign effectively framed the constitutional issue in terms of the public interest role of the legal profession and of the risk of eroding constitutional rights such as the right to fair trial and the right to privacy (Ali 2019). The Federation effectively co-opted antimoney laundering norms by introducing its own framework of disciplinary measures for enforcing the gatekeeping obligations prescribed by international organizations such as the FATF. Similar to the co-optation strategies identified in earlier scholarship on endogenous processes of legal norm construction (Edelman, Uggen, and Erlanger 1999), this measure proved effective in signaling compliance with the principles of the anti-money laundering regime while persuading national courts to restrict the use of penal regulation of lawyers' professional activities.

A processual approach to the study of transnational criminalization helps elucidate how landmark decisions by national courts form a part of ongoing, recursive processes of negotiating the scope and meaning of prohibition norms promulgated by international organizations. In its most recent evaluation report of Canada's anti-money laundering regulations, the FATF raised concerns regarding the implications of the Federation of Law Societies decision, and depicted it as a major source of vulnerability that could facilitate the misuse of legal services for purposes of money laundering and terrorism finance (FATF 2016, 15). The constitutional decision nonetheless impeded the implementation of the FATF policy scripts in Canada, and provided actors in other countries with a powerful precedent supporting constitutional challenges to domestic anti-money laundering laws (Ali 2019, 288-89). The case exemplifies the ways in which horizontal processes of legal diffusion can impede the efforts of international organizations to harmonize criminal laws across jurisdictions in a top-down manner (Halliday and Shaffer 2015, 60). National judges in different countries can develop a shared professional understanding of their role in checking and balancing the powers of international organizations and strategically use foreign legal sources to "reclaim democracy from the debilitating grip of globalization" (Benvenisti 2008, 242).

\section{Domestic Policing and Prosecutorial Practices in the Construction of Transnational Prohibition Norms}

Diagnostic struggles over whether to define certain behavior as criminal do not only affect legislative and judicial constructions of transnationally induced criminal laws. These struggles also shape the ways in which police officers, prosecutors, and other law enforcement agents apply these laws and determine their concrete meanings. Recent work in the sociology of criminalization has stressed the importance of

5. Canada (Attorney General) v. Federation of Law Societies of Canada, 2015 SCC 7, [2015] 1 S.C.R. 401. 
examining how law enforcement actors exercise interpretive discretion when deciding which acts and which perpetrators should be treated as criminal (Lacey 1995, 2009), reflective of growing sociolegal attention to the construction of legal meaning in everyday settings (Silbey 2005). The extent to which domestic law enforcement officials internalize the diagnostic frames underpinning a transnational prohibition norm plays a key role in shaping the degree to which national laws and local modes of enforcement concord with the settled meanings of that norm at the international level. Harold Koh's work on transnational legal processes predicts that the participation of domestic enforcement actors in transnational professional networks will facilitate processes of norm internalization (Koh 1996). According to this approach, the increasing participation of domestic law enforcement officials in supranational policing organizations such as Interpol, Europol, and the Financial Action Task Force facilitates the diffusion of security governance frames across jurisdictions (Bigo 2006; Bowling and Sheptycki 2012, 53-71).

However, a number of empirical studies suggest that the impact of transnational socialization mechanisms on the professional identities of national actors is weaker than predicted by Koh's theory (Hooghe 2005). Professional norms that are rooted in prior experiences in domestic bureaucracies and the socializing force of national cultures exert considerable influence on the attitudes and practices of actors implementing transnational policy scripts (Dezalay and Garth 1996; Hagan and Levi 2005). Mikkel Jarle Christensen's study of the struggle between professional groups in the Danish Prosecution Service shows how institutional inertia and bureaucratic pressures can marginalize transnationally embedded crime-governance perspectives even in a country that is considered to be an active and willing participant in international lawmaking processes (Christensen 2018). These findings support the view that legal definitions of crime-even more than interpretive constructions in other areas of law-ultimately reflect moral judgments that are deeply embedded in domestic cultural traditions (Nelken 2011b). When transnationally induced criminal law reforms do not resonate with widespread social conceptions about the wrongfulness of the prohibited form of conduct, they are likely to generate systematic patterns of underenforcement (Block-Lieb and Halliday 2015, 96-97). Over time, such patterns of underenforcement may become so deeply ingrained in the daily operation of domestic law enforcement agencies that they foster considerable ambiguity among the local population regarding whether the form of activity indeed is criminal (Kahan 2000). This theoretical insight helps to explain the minimal enforcement of domestic laws implementing transnational prohibition norms in a wide variety of issue areas. For example, the 1995 OECD Anti-Bribery Convention has been highly successful in prompting the organization's member states to pass new laws prohibiting the offering of bribes to foreign government officials. These enactments reflect a high degree of concordance between national laws and international norms. However, an examination of anticorruption enforcement patterns reveals that, during the treaty's first fifteen years, more than half of its state parties did not prosecute a single individual or firm for foreign bribery (Brewster 2014, 87). In a similar vein, despite the impressive transnational diffusion of laws criminalizing human trafficking in the wake of the Palermo Protocol, prosecution and conviction rates have remained stubbornly low. In 2015, it was reported that 41 percent of the countries 
that enacted such legislation recorded less than ten convictions in the period of 2010-2012 (Kangaspunta 2015, 86).

When criminal law is understood not only as a regulatory instrument but also as a medium of expressing and constituting collective moral values (Durkheim 1960), underenforcement of domestic laws implementing transnational prohibition norms demands attention to distinctive social meanings within wider struggles over global norms. James Scott's (1987, xvi) pioneering work on the social meanings of noncompliance shows how everyday practices of "foot-dragging, evasion, false compliance, pilfering, feigned ignorance, slander and sabotage" can serve as effective forms of expressing resistance to legal norms that are deemed illegitimate by the local population. Due to the mismatch between the international actors who produce transnational prohibition norms and the domestic actors implementing these norms in everyday settings, domestic law enforcement officials often turn a blind eye to social behaviors that might be classified as falling within the ambit of the statutory prohibitions that national legislatures enact under international pressure. Such practices of "foiling the hegemons" (Halliday and Carruthers 2009, ch. 9) contest the moral authority of powerful countries and international organizations to utilize the condemnatory voice of criminal law to export and universalize particular values. For example, ethnographic studies observe how the complicity of local police officers and actors from licit occupations (such as veterinarians and conservation officials) in facilitating the illegal trade in rhino horns in rural areas in South Africa reflected common views among local communities that the national laws prohibiting such trade were shaped by actors in the Global North and were not attentive to the adverse implications of such bans on rural African populations (Felbab-Brown 2017, 85). Similar observations apply to the implementation of laws criminalizing female genital cutting in sub-Saharan countries (Boyle 2002, 119).

By calling attention to the expressive meaning of domestic patterns of underenforcement of transnationally induced criminal laws, the transnational processual theoretical framework illustrates how the legitimacy deficits of coercive and other noninclusive techniques of producing transnational prohibition norms impede achieving their regulatory goals. Many of the legal ordering tools promoting the global diffusion of criminal prohibitions fail to satisfy standards of transparency, accountability, and inclusiveness (Boister 2003). The imposition of economic sanctions on countries that fail to conform to US-style models of criminalization and the publication of blacklists by the bureaucracies of international organizations provide two salient examples of a wider current in the transnational politics of criminalization (Friman 2015). The democratic deficits of such transnational legal ordering affect perceptions of their input legitimacy and compromise their ability to shape the normative commitments of domestic actors who implement them in everyday settings. The consequences of extensive reliance on coercive inducements during the formation of transnational criminalization processes are double-edged. These coercive pressures induce more states to adopt domestic laws implementing the policy scripts; however, they often do so at the cost of eroding the social conditions necessary for the effective enforcement of these laws. 


\section{RETHINKING THE IMPACT OF TRANSNATIONAL CRIMINALIZATION PROCESSES}

The preceding analysis has offered a new way of analyzing the formation, diffusion, implementation, and contestation of transnational prohibition norms under conditions of globalization. We identified a variety of strategies employed by transnational actors to harmonize criminal laws across jurisdictions. Many of these strategies enable powerful countries and international organizations (and, by extension, private constituencies that influence them) to deploy political and economic leverage to shape the direction of transnational criminalization processes. The transnational processual (TLO) approach, however, shows how the inevitable indeterminacy of prohibition norms, the contradictions they contain, the persistence of diagnostic struggles between competing frames for conceptualizing the targeted social problems, and the mismatch between the actors who craft prohibition norms in international lawmaking bodies and the actors who implement them in national and local contexts compromise the ability of powerful states to shape criminalization outcomes. What seems at first a triumph of powerful countries promoting the global diffusion of their preferred models of criminal legislation (McLeod 2010) stimulates lawmaking processes in unforeseen directions.

In contrast with theories that interpret the diffusion of prohibition norms as constituted by episodes of "global lawmaking from above," the transnational processual theoretical framework links macro-level processes of producing transnational norms with micro-level processes that shape their social meanings. In some cases, international pressures to implement global scripts of criminal legislation coincide with domestic cultural pressures to internalize the normative rationales expressed in these scripts into the daily practices of law enforcement agencies. In other cases, however, the contested legitimacy of the transnational legal ordering measures deployed to induce national legislatures to adopt prescribed definitions of transnational crimes may impede the normative internalization of these laws and spur domestic actors to develop tactics of resistance. It is thus wrong to assume that cross-national convergence of statutory definitions of crimes that enact international legal norms will catalyze a high degree of isomorphism in the everyday meanings of such offenses as reflected in practice (cf. Langer 2004; Lacey 2008). As Pierre Legrand $(1997,15)$ notes, "the meaning of a rule is not entirely supplied by the rule itself ... meaning is also-and perhaps mostly-a function of the application of the rule by its interpreter, of the concretization or instantiation in the events the rule is meant to govern." Such practices of translating the meaning of prohibition norms into domestic vernaculars shape the impact of these norms, potentially compromising their ability to achieve their advocates' goals.

By providing tools for systematic empirical investigation of the conditions that facilitate and hinder the concordance of prohibition norms across levels of government (from the international to the local), the processual theoretical framework raises questions about whether the means currently used to assess the impact of international instruments on domestic criminalization are capable of identifying the discordance between formal definitions of crime and their everyday implementation. Transnational criminalization processes often generate not only legislative outputs but also governance tools that measure the degree to which domestic policies comply 
with specified policy prescriptions (Merry 2016). Such governance tools tend to mainly observe changes in the formal laws and institutional design structures of national legal systems rather than the impact of such changes on domestic practice and the actual incidence of criminalized behavior. As David Nelken $(2015,39)$ observes, "[m]any indicators are set up to measure what can most easily be measured, irrespective of whether or not this gets at the heart of the problem." The failure of these instruments to penetrate beneath the surface of formal criminal prohibitions, in particular, reflects inherent methodological difficulties to accumulate and interpret data on changes in the incidence of illegal, clandestine activities (Andreas and Greenhill 2010). These governance instruments, while not resolving uncertainty regarding the "dark figure of crime," may nonetheless encourage national governments to adopt strategies of symbolic compliance that use treaty ratification and formal legislation to reap "rewards for positions rather than for effects" (Hathaway 2002, 2007).

From this vantage, the success of transnational criminalization processes in catalyzing the diffusion of criminal prohibitions may mask the persistent failure of states and international organizations to develop effective tools to address the root causes of the harmful activities being criminalized. In a scholarly tradition going back to Karl Marx's (1992) discussion of how the Factory Acts perpetuated the exploitative conditions inherent in the labor structures of early English industrial capitalism, critical strands in the sociology of criminalization have long observed that the introduction of criminal prohibitions targeting isolated symptoms of broader systems of exploitation can serve to disguise a lack of political will to dismantle the systemic conditions producing the harmful behaviors (Aaronson 2014). Transnational criminalization processes perform ideological functions in a period characterized by the global spread of economic policies that have led to growing inequality around the world. Consider, for example, the ideological dimension of the global spread of antitrafficking laws. The exploitation of migrant workers is shaped by structural conditions of extreme poverty in migrants' countries of origin and by the demand for cheap labor in destination countries (Kotiswaran 2017). To significantly reduce the incidence of human trafficking, the international community could prioritize transnational mechanisms that address various root causes, including the direct and indirect integration of forced and exploited labor into transnational production, destination countries' inadequate regulation of sex service industries, and the intensification of migrants' vulnerability to exploitation by harsh immigration policies. The success of norm entrepreneurs in placing antitrafficking criminal legislation at the center of the global policy agenda illustrates the double-edged consequences that transnational criminalization processes produce. While the emphasis on criminal legislation motivated national governments to pass and enforce laws against forms of exploitation that might otherwise have remained overlooked, it also enabled them to gain reputational points for their antitrafficking efforts, even when their efforts do little to address underlying causes.

This reading challenges a conventional triumphalist narrative that presumes the power of liberal internationalism to construct shared sentiments of moral condemnation across countries and regions (Sikkink 2011). An alternative narrative suggests that the willingness to condemn and penalize behavioral symptoms at times involves symbolic compensation for the diminishing capacities and will of governments to tackle underlying causes (Bauman 2000). Samuel Moyn, for example, observes similar dynamics in 
transnational criminalization processes shaping the legal definitions of war crimes. He traces how norm cascades to criminalize the humanitarian excesses of warfare, which the anti-impunity movement unleashed in the post-1980s, have eroded the principle that "war as a general phenomenon, not its cruelties alone, deserves most opprobrium" (Moyn 2020, 342). The activism that deploys criminal law to ensure morally tolerable conduct in warfare, in other words, has displaced ambitious visions of criminalizing the initiation of violent conflict. Where efforts to eliminate the root causes of international and transnational crimes do not accompany transnational criminalization processes, the success of these processes in initiating global waves of legal reform can obscure states' persistent failure to address the structural problems underpinning the crimes.

\section{CONCLUSION}

The transnational processual (TLO) theoretical framework developed and applied in this article offers a distinctive vantage from which to analyze the globalization of criminal law. The framework assesses the important role of states but challenges the conventional tendency to depict states as unitary actors monopolizing the power to define criminal prohibitions. Transnational processual theory rather assesses how state actors and institutions operate within both domestic and transnational political and social contexts that shape ongoing interpretive struggles over whether certain behaviors should be criminalized. The formation and diffusion of transnational prohibition norms largely rely on the coercive capacities of powerful states and on the symbolic authority of international organizations. The content of these norms, however, is shaped by a wide variety of private stakeholders and civil society actors using diverse legal mobilization tactics. The process of implementing transnational prohibition norms allows multiple actors operating within transnational, national, and local institutional settings to contest settled interpretations of criminal prohibitions and to shape their social meanings.

The processual theory set forth in this article facilitates empirical inquiry about the conditions under which instruments of transnational legal ordering emerge, transform, and affect behavior in international, national, and local sites of criminal lawmaking. To improve our understanding of how diagnostic struggles, legal indeterminacy, normative contradictions, and actor mismatch shape the ways in which actors negotiate the meaning of globalized criminal prohibitions, empirical studies can utilize a variety of qualitative methods such as systematic interviewing, participant observation, process tracing, content analysis, and surveys. Quantitative methods using large-N cross-national analyses to obtain data on those aspects of transnational criminalization processes that can be measured empirically (such as the relation of international crime suppression instruments to legislative trends and prosecutions, including through discourse analysis) will further advance our understanding of the relation of norm production and norm implementation within transnational criminalization processes. Given the focus of our processual theory on studying how ground-level actors assign meaning to prohibition norms in everyday settings, we believe that such quantitative methods would need to be combined with qualitative ones to provide a nuanced account of the varying contexts in which transnational legal ordering of criminalization operates and has effects. 
Our contribution in this article forms part of the wider effort of a New Legal Realism to develop analytical perspectives that oscillate between empirical findings, abstract theorizing, real-world testing, and back again (Erlanger et al. 2005; Nourse and Shaffer 2009). In this vein, future empirical work can both assess the theoretical claims that this article develops and help to reformulate them (cf. Kluttz and Fligstein 2016, 200-02). Whether using a qualitative, quantitative, or multimethod approach, such work will make an important contribution to the expanding body of empirical scholarship on the production and impact of international law (Shaffer and Ginsburg 2012). It will also make a much-needed contribution to the criminalization literature, given the relative scarcity of qualitative studies on how the meaning of criminal prohibitions is constructed "from below" in everyday settings (Schneider and Schneider 2008).

As long as national political communities continue to develop distinctive and sometimes irreconcilable conceptions of right and wrong, the isomorphic dynamics that transnational criminalization processes foster will not necessarily result in deeper convergence of legal practice. For some, this conclusion casts doubt on the ability of the international community to mitigate the economic, ecological, and political crises associated with contemporary processes of globalization. For others, it highlights the need to go beyond "tough-on-crime" approaches to address these challenges. To the extent that transnational criminalization processes focus on globalizing policy scripts that predominantly reflect powerful states' interests and perspectives on crime, they risk stretching the normative authority of criminal law beyond the point where its regulatory effectiveness can be assumed.

\section{REFERENCES}

Aaronson, Ely. From Slave Abuse to Hate Crime: The Criminalization of Racial Violence in American History. New York: Cambridge University Press, 2014.

—. "The Strange Career of the Transnational Legal Order of Cannabis Prohibition." UC Irvine Journal of International, Transnational, and Comparative Law 4 (2019): 79-96.

Aas, Katja Franko. Globalization $\mathcal{E}$ Crime. 2nd ed. London: Sage, 2013.

Abbott, Andrew. Processual Sociology. Chicago: The University of Chicago Press, 2016.

Abbott, Kenneth W. "Rule-Making in the WTO: Lessons from the Case of Bribery and Corruption." Journal of International Economic Law 4, no. 2 (2001): 275-96.

Alford, William. To Steal a Book Is an Elegant Offense: Intellectual Property Law in Chinese Civilization. Palo Alto, CA: Stanford University Press, 1997.

Ali, Nathanael Tilahun. "States' Varied Compliance with International Anti-Money Laundering Standards for Legal Professionals." Nordic Journal of International Law 88, no. 2 (2019): 280-307.

Andreas, Peter. "Illicit Globalization." In Globalisation, Criminal Law and Criminal Justice, edited by Valsamis Mitsilegas, Peter Alldridge, and Leonidas Cheliotis, 45-64. Oxford: Hart, 2015.

Andreas, Peter, and Ethan Nadelmann. Policing the Globe: Criminalization and Crime Control in International Relations. New York: Oxford University Press, 2006.

Andreas, Peter, and Kelly M. Greenhill. "The Politics of Measuring Illicit Flows and Policy Effectiveness." In Sex, Drugs, and Body Counts: The Politics of Numbers in Global Crime and Conflict, edited by Peter Andreas and Kelly M. Greenhill. Ithaca, NY: Cornell University Press, 2010.

Barnett, Michael, and Raymond Duvall. "Power in International Politics." International Organization 59, no. 1 (2005): 39-75. 
Barnett, Michael, and Martha Finnemore. Rules for the World: International Organizations in Global Politics. Ithaca, NY: Cornell University Press, 2004.

Bauman, Zygmunt. "Social Uses of Law and Order." In Criminology and Social Theory, edited by David Garland and Richard Sparks, 23-46. Oxford: Clarendon, 2000.

Beck, Ulrich, and Nathan Sznaider. "Unpacking Cosmopolitanism for the Social Sciences: A Research Agenda." British Journal of Sociology 61, no. 1 (2010): 381-403.

Benford, Robert, and David Snow. "Framing Processes and Social Movements: An Overview and Assessment." Annual Review of Sociology 26 (2000): 611-39.

Benvenisti, Eyal. "Reclaiming Democracy: The Strategic Uses of Foreign and International Law by National Courts." American Journal of International Law 102, no. 2 (2008): 241-74.

Bernstein, Elizabeth. "The Sexual Politics of the "New Abolitionism." Differences 18, no. 3 (2007): $128-51$.

Bewley-Taylor, David. International Drug Control: Consensus Fractured. New York: Cambridge University Press, 2012.

Bigo, Didier. "The Internal and External Aspects of Security." European Security 15, no. 4 (2006): 385-404.

Block-Lieb, Susan, and Terence C. Halliday. "Settling and Concordance: Two Cases in Global Commercial Law: Corporate Bankruptcy Law and International Trade by Sea." In Transnational Legal Orders, edited by Terence C. Halliday and Gregory Shaffer, 75-113. New York: Cambridge University Press, 2015.

- Global Lawmakers: International Organizations in the Crafting of World Markets. New York: Cambridge University Press, 2017.

Boister, Neil. “Transnational Criminal Law?" European Journal of International Law 14, no. 5 (2003): 953-76.

—. An Introduction to Transnational Criminal Law. New York: Oxford University Press, 2012.

Bowling, Ben. "Transnational Criminology and the Globalization of Social Harm." In What Is Criminology?, edited by Mary Bosworth and Carolyn Hoyle, 361-79. Oxford: Oxford University Press, 2011.

Bowling, Ben, and James Sheptycki. Global Policing. London: Sage, 2012.

Boyle, Elizabeth Heger. Female Genital Cutting: Cultural Conflict in the Global Community. Baltimore: Johns Hopkins University Press, 2002.

Boyle, Elizabeth Heger, and Sharon E. Preves. "National Policies as International Process: The Case of Anti-Female-Genital-Cutting Laws." Law EO Society Review 34, no. 3 (2000): 703-37.

Bradford, Anu. The Brussels Effect: How the European Union Rules the World. New York: Oxford University Press, 2020.

Brewster, Rachel. "The Domestic and International Enforcement of the OECD Anti-Bribery Convention." Chicago Journal of International Law 15, no. 1 (2014): 84-109.

Broude, Tomer, and Doron Teichman. "Outsourcing and Insourcing Crime: The Political Economy of Globalized Criminal Activity." Vanderbilt Law Review 62, no. 3 (2009): 795-848.

Bush, Jonathan A. "The Prehistory of Corporations and Conspiracy in International Law: What Nuremberg Really Said.” Columbia Law Review 109, no. 5 (2009): 1094-1262.

Calliess, Gralf-Peter, and Peer Zumbansen. Rough Consensus and Running Code: A Theory of Transnational Private Law. Portland: Hart, 2010.

Carruthers, Bruce, and Terence C. Halliday. "Negotiating Globalization: Global Scripts and Intermediation in the Construction of Asian Insolvency Regimes." Law $\mathcal{E}$ Social Inquiry 31, no. 3 (2006): 521-84.

Castells, Manuel. The Information Age: Economy, Society and Culture. Vol. 3: End of Millennium. 2nd ed. Oxford: Blackwell, 2010.

Christensen, Mikkel Jarle. "Reunited Europe and the Internationalization of Criminal Law: The Creation and Circulation of Criminal Law as an International Governance Tool." In International Practices of Criminal Justice: Social and Legal Perspectives, edited by Mikkel Jarle Christensen and Ron Levi, 17-35. New York: Routledge, 2017.

. "International Prosecution and National Bureaucracy: The Contest to Define International Practices within the Danish Prosecution Service." Law $\mathcal{E}$ Social Inquiry 43, no. 1 (2018): $152-81$. 
Christensen, Mikkel Jarle, and Ron Levi, eds. International Practices of Criminal Justice: Social and Legal Perspectives. New York: Routledge, 2017.

Chuang, Janie. "The United States as a Global Sheriff: Unilateral Sanctions and Human Trafficking." Michigan Journal of International Law 27, no. 2 (2006): 437-94.

__.,"Rescuing Trafficking from Ideological Capture: Prostitution Reform and Anti-Trafficking Law and Policy." University of Pennsylvania Law Review 158 (2010): 1655-1728.

_-.,"Exploitation Creep and the Unmaking of Human Trafficking Law." American Journal of International Law 108, no. 4 (2014): 609-49.

Claude, Inis. States and the Global System: Politics, Law and Organization. London: Macmillan Press, 1988.

Cotterrell, Roger. "What Is Transnational Law?" Law Ë Social Inquiry 37, no. 2 (2012): 500-24.

_ .,"The Concept of Crime and Transnational Networks of Community." In Globalisation, Criminal Law and Criminal Justice: Theoretical, Comparative and Transnational Perspectives, edited by Valsamis Mitsilegas, Peter Alldridge, and Leonidas Cheliotis, 7-24. Oxford: Hart, 2015.

Cryer, Robert, Darryl Robinson, and Sergey Vasiliev. An Introduction to International Criminal Law and Procedure. $4^{\text {th }}$ ed. New York: Cambridge University Press, 2017.

Darcy, Shane. "The Potential Role of Criminal Law in a Business and Human Rights Treaty." In Building a Treaty on Business and Human Rights: Context and Contours, edited by Surya Deva and David Bilchitz, 439-71. New York: Cambridge University Press, 2017.

Dezalay, Yves, and Bryant G. Garth. Dealing in Virtue: International Commercial Arbitration and the Construction of a Transnational Legal Order. Chicago: University of Chicago Press, 1996.

Duff, R.A., Lindsay Farmer, Sandra Marshall, Maximo Renzo, and Victor Tadros. "Introduction: Towards a Theory of Criminalization?" In Criminalization: The Political Morality of the Criminal Law, edited by R.A. Duff, Lindsay Farmer, Sandra Marshall, Maximo Renzo, and Victor Tadros, 1-54. Oxford: Oxford University Press, 2014.

Durkheim, Emil. The Division of Labour in Society. Translated by George Simpson. Glencoe, IL: Free Press, 1960.

Drezner, Daniel. All Politics Is Global. Princeton, NJ: Princeton University Press, 2007.

Edelman, Lauren, Christopher Uggen, and Howard Erlanger. "The Endogenity of Legal Regulation: Grievance Procedures as Rational Myth.” American Journal of Sociology 105, no. 2 (1999): 406-54.

Efrat, Asif. Governing Guns, Preventing Plunder: International Cooperation against Illicit Trade. New York: Oxford University Press, 2012.

Elliott, Jessica. The Role of Consent in Human Trafficking. New York: Routledge, 2015.

Erlanger, Howard, Bryant Garth, Jane Larson, Elizabeth Mertz, Victoria Nourse, and David Wilkins. "Forward: Is It Time for a New Legal Realism?" Wisconsin Law Review 2005 (2005): 335-63.

Felbab-Brown, Vanda. The Extinction Market: Wildlife Trafficking and How to Counter It. New York: Oxford University Press, 2017.

Financial Action Task Force (FATF). Anti-Money Laundering and Counter-Terrorist Financing Measures - Canada, Fourth Round Mutual Evaluation Report. 2016. https://www.fatf-gafi.org/publications/ mutualevaluations/documents/mer-canada-2016.html.

Finnemore, Martha. "Norms, Culture, and World Politics: Insights from Sociology's Institutionalism." International Organization 50, no. 2 (1996): 325-47.

Finnemore, Martha, and Kathryn Sikkink. "International Norm Dynamics and Political Change." International Organization 52, no. 4 (1998): 887-917.

Frank, David John, Kassia Wosick-Correa, and Tara Hardinge. "The Global Dimensions of Rape-Law Reform: A Cross-National Study of Policy Outcomes." American Sociological Review 74, no. 2 (2009): 272-90.

Friman, Richard. "Behind the Curtain: Naming and Shaming in International Drug Control." In The Politics of Leverage in International Relations: Name, Shame, and Sanction, edited by Richard Friman, 143-64. New York: Palgrave Macmillan, 2015.

Gallagher, Anne. "Human Rights and the New U.N. Protocols on Trafficking and Migrant Smuggling: A Preliminary Analysis.” Human Rights Quarterly 23 (2001): 975-1004. 
Gallagher, Anne, and Janie Chuang. "The Use of Indicators to Measure Government Responses to Human Trafficking." In Governance by Indicators: Global Power through Quantification and Ranking, edited by Kevin Davis, Angelina Fisher, Benedict Kingsbury, and Sally Engle Merry, 317-43. New York: Oxford University Press, 2012.

Gardner, Maggie. "Channeling Unilateralism." Harvard International Law Journal 56, no. 2 (2015): 297-351.

Goffman, Erving. Frame Analysis: An Essay on the Organization of Experience. Cambridge, MA: Harvard University Press, 1974.

Gould, Jon, and Scott Barclay. "Mind the Gap: The Place of Gap Studies in Sociolegal Scholarship." Annual Review of Law and Social Science 8 (2012): 323-35.

Grattet, Ryken, Valerie Jenness, and Theodore R. Curry. "The Homogenization and Differentiation of Hate Crime Law in the United States, 1978 to 1995." American Sociological Review 63, no. 2 (1998): 286-307.

Hafner-Burton, Emilie. Forced to Be Good: Why Trade Agreements Boost Human Rights. Ithaca, NY: Cornell University Press, 2009.

Hagan, John. "The Legislation of Crime and Delinquency: A Review of Theory, Method, and Research." Law Eु Society Review 14, no. 3 (1980): 603-28.

Hagan, John, and Scott Greer. "Making War Criminal." Criminology 40, no. 2 (2002): 231-64.

Hagan, John, and Ron Levi. "Crimes of War and the Force of Law." Social Forces 83, no. 4 (2005): 1499-1534.

Hagan, John, Ron Levi, and Gabrielle Ferrales. "Swaying the Hand of Justice: The Internal and External Dynamics of Regime Change at the International Criminal Tribunal for the Former Yugoslavia." Law E⿱ Social Inquiry 31, no. 3 (2006): 585-616.

Halliday, Terence C. "Recursivity of Global Lawmaking: A Sociolegal Agenda." Annual Review of Law and Social Science 5 (2009): 263-90.

— , and Bruce Carruthers. "The Recursivity of Law: Global Norm Making and National Lawmaking in the Globalization of Corporate Insolvency Regimes." American Journal of Sociology 112, no. 4 (2007a): 1135-1202.

Halliday, Terence C., and Bruce Carruthers. "Foiling the Financial Hegemons: Limits to the Globalisation of Corporate Insolvency Regimes in Indonesia, Korea and China." In Globalisation and Resistance: Law Reform in Asia since the Crisis, edited by Volkmar Gessner and Christopher Antons, 255-301. Oxford: Hart, 2007b.

Halliday, Terence C., and Bruce Carruthers. Bankrupt: Global Lawmaking and Systematic Financial Crisis. Palo Alto, CA: Stanford University Press, 2009.

Halliday, Terence C., Michael Levi, and Peter Reuter. "Anti-Money Laundering: An Inquiry into a Disciplinary Transnational Legal Order." UC Irvine Journal of International, Transnational, and Comparative Law 4 (2019): 1-26.

Halliday, Terence C., and Gregory Shaffer, eds. Transnational Legal Orders. New York: Cambridge University Press, 2015.

Hathaway, Oona. "Do Human Rights Treaties Make a Difference?" Yale Law Journal 111 (2002): 1935-2042.

Held, David, and Anthony McGrew. The Global Transformations Reader. Cambridge: Polity, 2003.

Henry, Stuart, and Mark Lanier, eds. What Is Crime?: Controversies over the Nature of Crime and What to Do about It. New York: Rowman \& Littlefield, 2001.

Hooghe, Liesbet. "Several Roads Lead to International Norms, but Few via International Socialization: A Case Study of the European Commission." International Organization 59, no. 4 (2005): 861-98.

Hulsman, Louk. "Critical Criminology and the Concept of Crime." Contemporary Crisis 10, no. 1 (1986): 63-80.

Jakobi, Anja P. Common Goods and Evils? The Formation of Global Crime Governance. New York: Oxford University Press, 2013.

Jenness, Valerie. "Explaining Criminalization: From Demography and Status Politics to Globalization and Modernization." Annual Review of Sociology 30 (2004): 147-71. 
Kahan, Dan. "Gentle Nudges vs. Hard Shoves: Solving the Sticky Norms Problem." The University of Chicago Law Review 67, no. 3 (2000): 607-45.

Kaleck, Wolfgang, and Miriam Saage-Maass. "Corporate Accountability for Human Rights Violations Amounting to International Crimes." Journal of International Criminal Justice 8 (2010): 699-724.

Kangaspunta, Kristiina. "Was Trafficking in Persons Really Criminalised?" Anti-Trafficking Review 4 (2015): 80-97.

Karpik, Lucien, and Terence C. Halliday. "The Legal Complex." Annual Review of Law and Social Science 7 (2011): 217-36.

Keck, Margaret, and Kathryn Sikkink. Activists beyond Borders: Advocacy Networks in International Politics. Ithaca, NY: Cornell University Press, 1998.

Kelley, Judith, and Beth Simmons. "Politics by Number: Indicators as Social Pressures in International Relations." American Journal of Political Science 59, no. 1 (2015): 55-70.

Kluttz, Daniel, and Neil Fligstein. "Varieties of Sociological Field Theory." In Handbook of Contemporary Sociological Theory, edited by Seth Abrutyn, 185-203. New York: Springer, 2016.

Knepper, Paul. The Invention of International Crime: A Global Issue in the Making, 1881-1914. New York: Palgrave Macmillan, 2010.

Koh, Harold Hongju. "Transnational Legal Process." Nebraska Law Review 75 (1996): 181-207.

Kotiswaran, Prabha. Dangerous Sex, Invisible Labour: Sex Work and the Law in India. New York: Oxford University Press, 2011.

—., ed. Revisiting the Law and Governance of Trafficking, Forced Labor and Modern Slavery. New York: Cambridge University Press, 2017.

—. "Transnational Criminal Law in a Globalised World: The Case of Trafficking." UC Irvine Journal of International, Transnational, and Comparative Law 4 (2019): 52-77.

Kotiswaran, Prabha, and Nicola Palmer. "Rethinking the 'International Law of Crime': Provocations from Transnational Legal Studies." Transnational Legal Theory 6, no. 1 (2015): 55-88.

Krisch, Nico. "The Decay of Consent: International Law in an Age of Global Public Goods." American Journal of International Law 108, no. 1 (2014): 1-40.

Lacey, Nicola. "Contingency and Criminalisation." In The Frontiers of Criminality, edited by Ian Loveland, 1-27. London: Sweet and Maxwell, 1995.

—. The Prisoners' Dilemma: Political Economy and Punishment in Contemporary Democracies. Cambridge: Cambridge University Press, 2008.

_. "Historicising Criminalisation: Conceptual and Empirical Issues." Modern Law Review 72, no. 6 (2009): 936-60.

Lacey, Nicola, and Lucia Zedner. "Criminalization: Historical, Legal, and Criminological Perspectives." In The Oxford Handbook of Criminology, 6th ed., edited by Alison Liebling, Shadd Maruna, and Lesley McAra, 57-76. Oxford: Oxford University Press, 2017.

Langer, Maximo. "From Legal Transplants to Legal Translations: The Globalization of Plea Bargaining and the Americanization Thesis in Criminal Procedure." Harvard International Law Journal 45, no. 1 (2004): 1-64.

Laqueur, Hanna. "Uses and Abuses of Drug Decriminalization in Portugal." Law $\mathcal{E}$ Social Inquiry 40, no. 3 (2015): 746-81.

Legrand, Pierre. "The Impossibility of Legal Transplants." Maastricht Journal of European and Comparative Law 4 (1997): 111-24.

Levi, Ron, John Hagan, and Sara Dezalay. "International Courts in Atypical Political Environments: The Interplay of Prosecutorial Strategy, Evidence, and Court Authority in International Criminal Law." Law EO Contemporary Problems 79, no. 1 (2016): 289-314.

Liu, Sida. "The Legal Profession as a Social Process: A Theory on Lawyers and Globalization." Law $\mathbb{E}$ Social Inquiry 38, no. 3 (2013): 670-93.

Liu, Sida, and Terence C. Halliday. "Recursivity in Legal Change: Lawyers and Reforms of China's Criminal Procedure." Law Eु Social Inquiry 34, no. 4 (2009): 911-50.

MacKinnon, Catharine A. "Prostitution and Civil Rights." Michigan Journal of Gender and Law 1 (1993): 13-31.

Marx, Karl. Capital (Vol. 1): A Critique of the Political Economy. London: Penguin, 1992 [1857]. 
McLeod, Allegra. "Exporting US Criminal Justice." Yale Law $\mathcal{G}$ Policy Review 29, no. 1 (2010): $84-164$.

Meierhenrich, Jens. "The Practice of International Law: A Theoretical Analysis." Law $\mathcal{E}$ Contemporary Problems 76, no. 1 (2014): 1-83.

Merry, Sally Engle. Human Rights and Gender Violence: Translating International Law into Local Justice. Chicago: University of Chicago Press, 2006a.

—. "Transnational Human Rights and Local Activism: Mapping the Middle." American Anthropologist 108, no. 1 (2006b): 38-51.

. The Seduction of Quantification: Measuring Human Rights, Gender Violence, and Sex Trafficking. Chicago: University of Chicago Press, 2016.

. "Conclusion: A Processual Approach to Transnational Legal Orders." In Transnational Legal Ordering of Criminal Justice, edited by Gregory Shaffer and Ely Aaronson, 369-80. New York: Cambridge University Press, 2020.

Merry, Sally Engle, Kevin E. Davis, and Benedict Kingsbury, eds. The Quiet Power of Indicators: Measuring Governance, Corruption, and Rule of Law. New York: Cambridge University Press, 2015.

Meyer, John W., John Boli, George M. Thomas, and Francisco O. Ramirez. "World Society and the Nation State." American Journal of Sociology 103, no. 1 (1997): 144-81.

Mitsilegas, Valsimis. "The EU and the Global Governance of Crime." In Globalisation, Criminal Law and Criminal Justice, edited by Valsimis Mitsilegas, Peter Alldridge, and Leonidas Cheliotis, 15398. Oxford: Hart, 2015.

Moyn, Samuel. "From Aggression to Atrocity: Rethinking the History of International Criminal Law." In The Oxford Handbook of International Criminal Law, edited by Kevin Heller, Frédéric Mégret, Sarah Nouwen, and Darryl Robinson, 341-60. New York: Oxford University Press, 2020.

Nadelmann, Ethan. "Global Prohibition Regimes: The Evolution of Norms in International Society." International Organization 44, no. 4 (1990): 479-526.

Nance, Mark. "The Regime that FATF Built: An Introduction to the Financial Action Task Force." Crime, Law, and Social Change 69, no. 2 (2018): 109-29.

Naylor, R.T. Wages of Crime: Black Markets, Illegal Finance, and the Underworld Economy. Ithaca, NY: Cornell University Press, 2002.

Nelken, David. "Introduction: Comparative Criminal Justice and the Challenge of Globalisation." In Comparative Criminal Justice and Globalization, edited by David Nelken, 1-10. Farnham: Ashgate, 2011a.

—. "Theorising the Embeddedness of Punishment." In Travels of the Criminal Question: Cultural Embeddedness and Diffusion, edited by Dario Melossi, Maximo Sozzo, and Richard Sparks, 6594. Oxford: Hart, 2011b.

. "Transnational Legal Processes and the (Re)Construction of the 'Social': The Case of Human Trafficking." In Exploring the 'Socio' of Socio-Legal Studies, edited by Dermot Feenan, 137-56. New York: Palgrave Macmillan, 2013.

—. "The Changing Role of Social Indicators: From Explanation to Governance." In Globalisation, Criminal Law and Criminal Justice: Theoretical, Comparative and Transnational Perspectives, edited by Valsamis Mitsilegas, Peter Alldridge, and Leonidas Cheliotis, 25-44. Oxford: Hart, 2015.

Nourse, Victoria, and Gregory Shaffer. "Varieties of New Legal Realism: Can a New World Order Prompt a New Legal Theory?" Cornell Law Review 95 (2009): 61-137.

Office of the Prosecutor of the International Criminal Court. Policy Paper on Case Selection and Prioritisation. 2016. https://www.icc-cpi.int/itemsDocuments/20160915_OTP-Policy_CaseSelection_Eng.pdf.

Pauwelyn, Joost, Ramses Wessel, and Jan Wouters, eds. Informal International Lawmaking. New York: Oxford University Press, 2012.

Putnam, Robert. "Diplomacy and Domestic Politics." International Organization 42, no. 3 (1998): $427-60$.

Reiner, Robert. Crime. Cambridge: Polity, 2016.

Romaniuk, Peter. "Institutions as Swords and Shields: Multilateral Counter-Terrorism since 9/11." Review of International Studies 36, no. 3 (2010): 591-613. 
Sassen, Saskia. "When the Global Arises from inside the National." In Educators, Professionalism and Politics: Global Transitions, National Spaces and Professional Projects, edited by Terri Seddon and John Levin, 27-41. New York: Routledge, 2013.

Schneider, Jane, and Peter Schneider. "The Anthropology of Crime and Criminalization." Annual Review of Anthropology 37 (2008): 351-73.

Scott, James. Weapons of the Weak: Everyday Forms of Peasant Resistance. New Haven, CT: Yale University Press, 1987.

Sell, Susan. Private Power, Public Law: The Globalization of Intellectual Property Rights. New York: Cambridge University Press, 2003.

Shaffer, Gregory. "Transnational Legal Process and State Change." Law ES Social Inquiry 37, no. 2 (2012): 229-64.

—. ed. Transnational Legal Ordering and State Change. New York: Cambridge University Press, 2013.

—_, "How the World Trade Organization Shapes Regulatory Governance." Regulation and Governance 9, no. 1 (2015): 1-15.

_ 2016. "Theorizing Transnational Legal Orders." Annual Review of Law and Social Science 12 (2016): 231-53.

Shaffer, Gregory, and Tom Ginsburg. 2012. "The Empirical Turn in International Legal Scholarship." American Journal of International Law 106, no. 1 (2012): 1-46.

Shaffer, Gregory, Nathaniel Nesbitt, and Spencer Weber Waller. "Criminalizing Cartels: A Global Trend?" In Research Handbook on Comparative Competition Law, edited by John Duns, Arlen Duke, and Brendan Sweeney, 301-44. Cheltenham: Edgar Elgar, 2015.

Shaffer, Gregory, and Terrence Halliday. "With, within, and beyond the State: The Promise and Limits of Transnational Legal Ordering." In The Oxford Handbook of Transnational Law, edited by Peer Zumbansen. New York: Oxford University Press, forthcoming.

Shaffer, Gregory, Tom Ginsburg, and Terrence Halliday, eds. Constitution-Making and Transnational Legal Order. New York: Cambridge University Press, 2019.

Shaffer, Gregory, and Ely Aaronson, eds. Transnational Legal Ordering of Criminal Justice. New York: Cambridge University Press, 2020.

Shamir, Ronen, and Dafna Hacker. "Colonialism's Civilizing Mission: The Case of the Indian Hemp Drug Commission." Law $\mathcal{E}$ Social Inquiry 26, no. 2 (2001): 435-61.

Sharman, J. C. The Money Laundry: Regulating Criminal Finance in the Global Economy. Ithaca, NY: Cornell University Press, 2011.

Sikkink, Kathryn. The Justice Cascade: How Human Rights Prosecutions Are Changing World Politics. New York: W. W. Norton, 2011.

Silbey, Susan. "After Legal Consciousness." Annual Review of Law and Social Science 1 (2005): 323-68.

Slaughter, Anne-Marie. A New World Order. Princeton: Princeton University Press, 2004.

Stuntz, William. "The Pathological Politics of Criminal Law." Michigan Law Review 100, no. 3 (2001): $506-600$.

Walker, Neil. Intimations of Global Law. New York: Cambridge University Press, 2014.

Weiner, Antje. Contestation and Constitution of Norms in Global International Relations. New York: Cambridge University Press, 2018.

Williams, Phil, and Dimitri Vlassis, eds. Combating Transnational Crime: Concepts, Activities, and Responses. London: Routledge, 2001.

Wimmer, Andreas, and Nina Glick Schiller. "Methodological Nationalism, the Social Sciences, and the Study of Migration: An Essay in Historical Epistemology." International Migration Review 3, no. 3 (2003): 576-610.

Yoo, Eun-hye, and Elizabeth Heger Boyle. "National Human Trafficking Initiatives: Dimensions of Policy Diffusion." Law Eु Social Inquiry 40, no. 3 (2015): 631-63. 